\title{
Physiologic variations of serum tumor markers in gynecological malignancies during pregnancy: a systematic review
}

\author{
Sileny N Han ${ }^{1}$, Anouk Lotgerink ${ }^{2}$, Mina Mhallem Gziri ${ }^{3}$, Kristel Van Calsteren ${ }^{3}$, Myriam Hanssens ${ }^{3}$ and
} Frédéric Amant ${ }^{1 *}$

\begin{abstract}
Background: Recent insights provide support for the treatment of cancer during pregnancy, a coincidence that poses both mother and fetus at risk. Our aim was to critically review studies on the physiologic variations during pregnancy, the most common tumor markers used in diagnosis and follow-up of gynecological cancers.

Methods: We conducted a systematic review of six tumor markers during normal pregnancy: carbohydrate antigen (CA) 15-3 (breast cancer); squamous cell carcinoma antigen (cervical cancer); and CA 125, anti-Müllerian hormone, inhibin B and lactate dehydrogenase (ovarian cancer).

Results: For CA $15-3,3.3 \%$ to $20.0 \%$ of all measurements were above the cut-off (maximum $56 \mathrm{U} / \mathrm{mL}$ in the third trimester). Squamous cell carcinoma antigen values were above cut-off in $3.1 \%$ and $10.5 \%$ of the measurements (maximum $4.3 \mu \mathrm{g} / \mathrm{L}$ in the third trimester). Up to 35\% of CA 125 levels were above cut-off: levels were highest in the first trimester, with a maximum value up to $550 \mathrm{U} / \mathrm{mL}$. Inhibin B, anti-Müllerian hormone and lactate dehydrogenase levels were not elevated in maternal serum during normal pregnancy.

Conclusion: During normal pregnancy, tumor markers including CA 15.3, squamous cell carcinoma antigen and CA 125 can be elevated; inhibin B, anti-Müllerian hormone and lactate dehydrogenase levels remain below normal cut-off values. Knowledge of physiological variations during pregnancy can be clinically important when managing gynecological cancers in pregnant patients.
\end{abstract}

Keywords: anti-Müllerian hormone, CA 125; CA 15-3, cancer, human epididymis secretory protein 4 (HE4), inhibin $B$, lactate dehydrogenase, pregnancy, squamous-cell carcinoma antigen tumor markers

\section{Background}

Tumor markers are biochemical substances found in the presence of cancer and produced either by the tumor itself or in response to (para)neoplastic conditions, such as inflammation. Tumor markers can be found in a variety of bodily fluids and tissues and include hormones and several subgroups of (glyco)proteins, such as oncofetal antigens (which are normally expressed during fetal life), enzymes and receptors. They are used for diagnosis, assessment of therapeutic efficacy, and detecting recurrence during follow-up. The most limiting factor in the

\footnotetext{
* Correspondence: frederic.amant@uzleuven.be

'Leuven Cancer Institute, Gynecologic Oncology, University Hospitals Leuven, KU Leuven, Belgium

Full list of author information is available at the end of the article
}

clinical use of tumor markers is the lack of sensitivity and specificity because the majority of markers are tumorassociated rather than tumor-specific; elevated levels can occur in different types of malignancies as well as in benign and physiological conditions such as pregnancy [1]. Moreover, early diagnosis and treatment of recurrences that are solely detected by the use of tumor marker alone has not shown survival benefit [2].

It is estimated that one in 1,000 to 2,000 pregnant women are diagnosed with an intercurrent malignancy, at an average age of 33 years [3]. Moreover, a slowly rising incidence rate has been observed since the 1960s [4]. Breast cancer, hematological malignancies and cervical cancer are the most commonly encountered malignancies during pregnancy [3]. Pregnancy after oncologic
C Biomed Central

(C) 2012 Han et al; licensee BioMed Central Ltd. This is an Open Access article distributed under the terms of the Creative Commons Attribution License (http://creativecommons.org/licenses/by/2.0), which permits unrestricted use, distribution, and reproduction in any medium, provided the original work is properly cited. 
treatment is also becoming more common, mainly due to advances in fertility-sparing treatment and improved prognosis [5]. Diagnosis and treatment of these two types of patients cannot always be extrapolated from the nonpregnant patient; this is also the case when interpreting tumor markers during pregnancy. Unawareness of pregnancy-related physiologic elevations of tumor markers may lead to the search for metastatic disease, using extensive and unnecessary diagnostic examinations that are costly and uncomfortable, and also expose the fetus to avoidable radiation.

At present, the number of studies conducted on serum tumor markers during pregnancy is limited. Our goal is to review existing publications on this topic, and also to provide an easily accessible table of reference values during pregnancy for the most common tumor markers used in cases of gynecological malignancies.

\section{Methods}

We focused on six tumor markers that are well-established in gynecological cancers and are used for breast cancer (carbohydrate antigen (CA) 15-3), cervical squamous cell cancer (squamous cell carcinoma antigen (SCC)), and ovarian cancer (CA 125 for epithelial ovarian tumors, inhibin B and anti-Müllerian hormone (AMH) for sex cord-stromal tumors, and lactate dehydrogenase (LDH) for germ cell tumors). We conducted a systematic literature search in MEDLINE to identify relevant publications from 1 January 1980 to 31 September 2011 in the English language. Additional publications were identified from the reference lists of relevant articles (Figure 1). The systematic search was conducted using the following medical subject headings (MeSH) terms, words and combinations of words: pregnancy AND CA 15-3, squamouscell carcinoma antigen, CA 125, inhibin B, anti-Müllerian hormone, lactate dehydrogenase. Two investigators $(\mathrm{SH}$ and AL) independently identified potentially relevant articles using the title and the abstract. Eligibility criteria were as follows: firstly, when the maternal serum tumor marker was studied in healthy pregnant women without medical or obstetric confounding conditions, and secondly, if the gestational age was reported by trimester. For inhibin, we excluded older publications that used assays unable to differentiate between dimeric forms and thus were nondiscriminatory between inhibin A and B. Due to the diverse study designs and conditions and use of different assay methods with different intra-and interassay coefficients of variation, a meta-analysis was not possible.

$\alpha$-fetoprotein and the $\beta$ subunit of human chorionic gonadotropin are both substances that are abundantly present during gestation and have been extensively investigated. Reference values during pregnancy are available in most laboratories, hence we did not include these two markers in our review.

\section{Results}

The database search provided 1,786 articles for the six tumor markers combined. After an initial review of the title and abstract, 54 articles appeared to be relevant and were retrieved to be reviewed in full. Twenty-six studies met our inclusion criteria and were included in the review. Table 1 provides a short summary of the general characteristics of the tumor markers (clinical use, molecular weight and production site). Definitions on the three trimesters of pregnancy varied between publications. The first trimester was defined as the period between the beginning of pregnancy up to 12 to 14 weeks' gestation; the second trimester was defined as the period from the end of the first trimester up to 24 to 28 weeks' gestation, after which began the third trimester until delivery. For each tumor marker, data were extracted from as many studies as possible. These ranges were combined to establish a normal reference range per trimester (Table 2). Cut-off values used in clinical oncology for non-pregnant adults are as stated in the publications and also listed in Table 2.

\section{Breast cancer}

\section{Cancer antigen 15-3}

As illustrated in Table 3, CA 15-3 values were described in six publications [6-11], of which two $(n=12$ and $n=30)$ had a longitudinal design $[7,11]$. Although values largely remained below the cut-off, a significantly increased level was observed during pregnancy in five of the six studies, with the highest levels occurring in the third trimester. In three of the four most recent studies, between $3.3 \%$ and $20 \%$ of all measurements were found to be above the cutoff value [8-11]. The highest reported CA $15-3$ value was $56 \mathrm{U} / \mathrm{mL}$ in the third trimester [10].

\section{Cervical cancer}

\section{Squamous cell carcinoma antigen}

Physiological circulating levels of SCC throughout gestation have only been reported in two studies to date [6,7]. In 1989, Touitou et al. [6] published a cross-sectional study of maternal serum SCC including 32, 32, and 36 women in each of the three pregnancy trimesters, respectively. The observed SCC levels were $0.77 \mu \mathrm{g} / \mathrm{L} \pm 0.60$ (mean $\pm \mathrm{SD}), 1.25 \mu \mathrm{g} / \mathrm{L} \pm 0.37$ and $1.10 \mu \mathrm{g} / \mathrm{l} \pm 0.56$ for the first, second and third trimester, respectively. The SCC levels were significantly higher in the second and third trimesters when compared with the first trimester. The mean concentrations stayed well within the normal range whilst $3.1 \%$ of participants had levels exceeding the cut-off value (exact cut-off not 


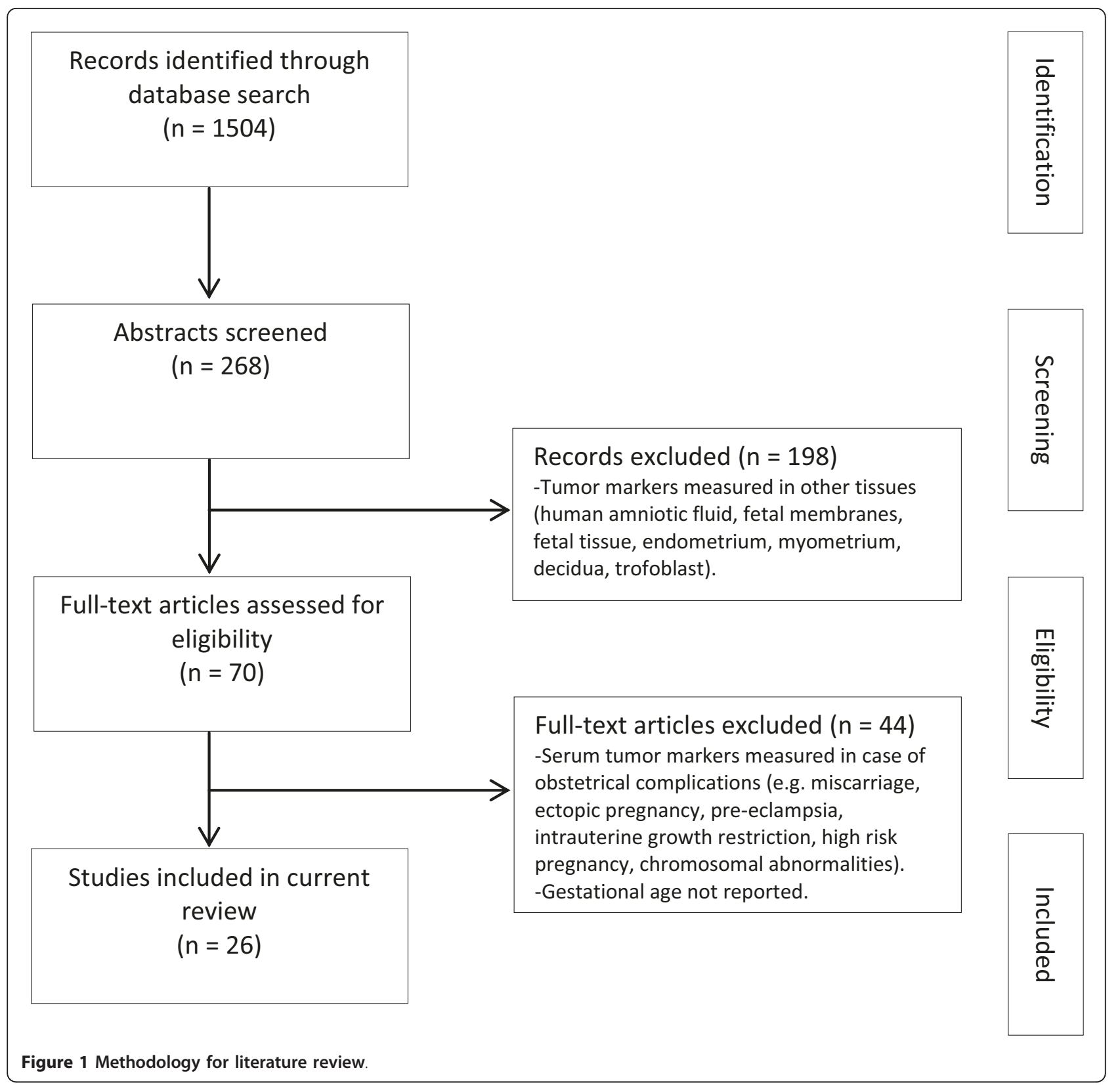

stated) [6]. In 1998, Schlageter et al. [7] obtained four to nine serum samples from each of 12 healthy pregnant women serially throughout gestation. They also observed higher levels in the third trimester, although mean levels remained below the cut-off throughout the entire pregnancy. SCC concentrations were found to exceed the cut-off value of $1.6 \mu \mathrm{g} / \mathrm{L}$ in $10.5 \%$ of samples (range 0.1 to $4.3 \mu \mathrm{g} / \mathrm{L})$.

\section{Epithelial ovarian cancer}

\section{Cancer antigen 125}

Although CA 125 is the most studied tumor marker in pregnancy, the different reports are contradictory. We found ten publications $[7,10-18]$, of which four had a longitudinal study design $[7,11,15,18]$; an overview is shown in Table 4. Elevated levels were found in all ten studies, in up to $35 \%$ of the measurements. CA 125 levels were uniformly reported to be highest in the first trimester, with a maximum value up to $550 \mathrm{U} / \mathrm{mL}$ [13]. For the second and third trimester, mean maternal CA 125 values were found generally below the cut-off value and remaining below this level until delivery. Nonetheless, four studies found elevated levels up to $73 \mathrm{U} / \mathrm{mL}$ in the second trimester $[7,10,13,17]$, and eight studies found elevated levels in the third trimester $[7,10,11,13-17]$, with a maximum level of 2,419.7 U/mL. 
Table 1 Tumor marker characteristics.

\begin{tabular}{|c|c|c|c|c|}
\hline $\begin{array}{l}\text { Tumor } \\
\text { marker }\end{array}$ & $\begin{array}{l}\text { Clinical use in } \\
\text { gynecological } \\
\text { oncology }\end{array}$ & Production site in normal adult & $\begin{array}{l}\text { Production site during } \\
\text { pregnancy }\end{array}$ & $\begin{array}{l}\text { Molecular } \\
\text { weight }\end{array}$ \\
\hline $\begin{array}{l}\text { Carbohydrate } \\
\text { antigen } 15-3\end{array}$ & Breast cancer & Glandular epithelia & $\begin{array}{l}\text { Uncertain } \\
\text { (maternal mammary } \\
\text { gland epithelium? } \\
\text { placenta?) }\end{array}$ & $290 \mathrm{kDa}$ \\
\hline $\begin{array}{l}\text { Squamous cell } \\
\text { carcinoma } \\
\text { antigen }\end{array}$ & $\begin{array}{l}\text { Cervical squamous } \\
\text { cell cancer }\end{array}$ & Squamous epithelia (both benign and malignant) & $\begin{array}{l}\text { Uncertain } \\
\text { (fetus?) }\end{array}$ & $42 \mathrm{kDa}$ \\
\hline $\begin{array}{l}\text { Carbohydrate } \\
\text { antigen } 125\end{array}$ & $\begin{array}{l}\text { Non-mucinous } \\
\text { ovarian cancer }\end{array}$ & $\begin{array}{l}\text { Structures derived from the celomic epithelium (such as } \\
\text { endocervix, endometrium, and fallopian tube) and in tissues } \\
\text { developed from mesothelial cells (such as pleura, pericardium } \\
\text { and peritoneum) }\end{array}$ & $\begin{array}{l}\text { Decidua and amnion } \\
\text { cells }\end{array}$ & 200 to $250 \mathrm{kDa}$ \\
\hline Inhibin B & $\begin{array}{l}\text { Granulosa cell } \\
\text { tumors } \\
\text { (some (mucinous) } \\
\text { epithelial ovarian } \\
\text { tumors) }\end{array}$ & $\begin{array}{l}\text { Granulosa and theca cells (member of the transforming growth } \\
\text { factor- } \beta \text { family) }\end{array}$ & Granulosa and theca cells & $\begin{array}{l}\text { Monomer } \\
15 \mathrm{kDa} \text {, } \\
\text { homodimer } \\
25 \mathrm{kDa}\end{array}$ \\
\hline $\begin{array}{l}\text { Anti-Müllerian } \\
\text { hormone }\end{array}$ & $\begin{array}{l}\text { Granulosa cell } \\
\text { tumors }\end{array}$ & $\begin{array}{l}\text { Granulosa cells of ovarian follicles (member of the transforming } \\
\text { growth factor- } \beta \text { family) }\end{array}$ & $\begin{array}{l}\text { Sertoli cells of male fetus, } \\
\text { for regression of } \\
\text { Müllerian ducts }\end{array}$ & $140 \mathrm{kDa}$ \\
\hline $\begin{array}{l}\text { Lactate } \\
\text { dehydrogenase }\end{array}$ & Germ cell tumors & Cell cytoplasm & Cell cytoplasm & $140 \mathrm{kDa}$ \\
\hline
\end{tabular}

\section{Sex cord-stromal tumor Inhibin B}

To date, two studies have measured inhibin B levels in healthy pregnant women longitudinally during gestation. Petraglia et al. [19] followed 13 pregnant women: mean \pm $\mathrm{SD}$ values showed that serum inhibin B levels during the first $(27.50 \pm 2.72 \mathrm{ng} / \mathrm{L})$ and second $(38.00 \pm 9.06 \mathrm{ng} / \mathrm{L})$ trimester were significantly lower than at the third trimester $(115.5 \pm 28.19 \mathrm{ng} / \mathrm{L} ; P<0.001)$. Values at term were significantly higher than in their control group of nonpregnant women during the early follicular and early luteal phases of the menstrual cycle $(P<0.01)$. Fowler et al. [20] measured inhibin $B$ in six healthy pregnant women and found that concentrations of inhibin $B$ fell to undetectable concentrations $(<12 \mathrm{ng} / \mathrm{L})$ during the first half of pregnancy and only increased slightly in the second half to a maximum concentration of $25 \mathrm{ng} / \mathrm{L}$, which was still well below the normal cut-off level for the non-pregnant premenopausal adult female (and 200-fold lower than inhibin A levels). Wallace et al. [21] found undetectable inhibin B levels in maternal serum from 807 pregnancies with 10 to 20 weeks' gestational age.

Table 2 Overview of ranges during pregnancy per tumor marker.

\begin{tabular}{|c|c|c|c|c|c|}
\hline & $\begin{array}{l}\text { Normal oncologic cut-off values in non- } \\
\text { pregnant women }\end{array}$ & Trimester $1^{a}$ & Trimester 2 & Trimester 3 & References \\
\hline \multirow[t]{2}{*}{ Carbohydrate antigen $15-3^{b}$} & $<30 \mathrm{U} / \mathrm{mL}$ & 5.0 to 39.3 & 1.0 to 40 & 7.0 to 56 & {$[7,11,51,52]$} \\
\hline & & 1.3 to 19.5 & 4.0 to 24.4 & 7.0 to 27 & {$[6,7]$} \\
\hline \multirow{2}{*}{$\begin{array}{l}\text { Squamous cell carcinoma } \\
\text { antigen }\end{array}$} & $<2 \mu \mathrm{g} / \mathrm{L}$ & 0.3 to 2.9 & 0.1 to 2.2 & 0.6 to 4.3 & {$[7]$} \\
\hline & & 0 to 1.97 & 0.51 to 1.99 & 0 to 2.22 & {$[6]$} \\
\hline \multirow[t]{2}{*}{ Carbohydrate antigen 125} & $<39 \mathrm{U} / \mathrm{mL}$ & 3.7 to 550 & 1 to 166.6 & 6.1 to $2,419.7$ & {$[7,10,11,13,14,17,18]$} \\
\hline & & 0 to 215.1 & 0 to 308 & 0 to 56.3 & {$[15,16]$} \\
\hline \multirow[t]{2}{*}{ Inhibin B } & $\mathrm{ng} / \mathrm{mL}$ & NA & NA & NA & NA \\
\hline & & $\begin{array}{l}22.06 \text { to } \\
32.94\end{array}$ & $\begin{array}{l}19.88 \text { to } \\
56.12\end{array}$ & $\begin{array}{l}58.62 \text { to } \\
171.38\end{array}$ & {$[19]$} \\
\hline \multirow[t]{2}{*}{ Anti-Müllerian hormone } & $\mathrm{ng} / \mathrm{mL}$ & 0.2 to 9.3 & 0.5 to 4.0 & 0.2 to 3 & {$[22,23]$} \\
\hline & & NA & NA & NA & NA \\
\hline \multirow[t]{2}{*}{ Lactate dehydrogenase } & $<221 \mathrm{U} / \mathrm{L}$ & 78 to 433 & 80 to 447 & 82 to 524 & {$[25-28]$} \\
\hline & & NA & NA & NA & NA \\
\hline
\end{tabular}

NA, not applicable. ${ }^{a}$ The definition of first, second and third trimester is the one used in the study and differs from one study to the other; ${ }^{\mathrm{b}}$ for each parameter the non-pregnant reference value is the mean of all studies, whereas lowest and highest ranges and 2.5 to 97.5 percentiles in the three pregnancy trimesters are presented in the first and the second row, respectively. 
Table 3 Overview of selected studies on carbohydrate antigen 15-3 levels during normal pregnancy.

\begin{tabular}{|c|c|c|c|c|c|c|c|c|c|}
\hline & $\begin{array}{l}\text { Author/year of } \\
\text { publication }\end{array}$ & $\begin{array}{l}\text { Study } \\
\text { design }\end{array}$ & Laboratory technique & Number of patients & $\begin{array}{l}\text { Cut-off } \\
\text { value }\end{array}$ & $\begin{array}{l}\text { Trimester } \\
1\end{array}$ & Trimester 2 & Trimester 3 & Conclusion \\
\hline 1 & Touitou 1989 [6] & $\begin{array}{l}\text { cross- } \\
\text { sectional }\end{array}$ & $\begin{array}{l}\text { IRMA, CIS-Bio International, Gif- } \\
\text { Sur-Yvette, France }\end{array}$ & $\begin{array}{l}\text { T1 } \mathrm{n}=32 ; \mathrm{T} 2 \mathrm{n}=32 \\
\mathrm{~T} 3 \mathrm{n}=36\end{array}$ & $<25$ & $\begin{array}{l}11.1 \pm 4.2 \\
\text { mean } \pm \text { SD }\end{array}$ & $14.2 \pm 5.1$ & $17.0 \pm 5.0$ & None above cut-off value \\
\hline 2 & $\begin{array}{l}\text { Schlageter } 1998 \\
\text { [7] }\end{array}$ & longitudinal & $\begin{array}{l}\text { ELSA-CA 15-3 (CIS-Bio } \\
\text { International), Gif-Sur-Yvette, } \\
\text { France }\end{array}$ & $\mathrm{n}=12$ & $<30$ & $\begin{array}{l}9.3 \pm 4.0 \\
\text { (mean } \pm \\
\text { SD) } \\
5 \text { to } 15 \\
\text { (range) }\end{array}$ & $\begin{array}{l}14.1 \pm 4.1 \\
10 \text { to } 22.8\end{array}$ & $\begin{array}{l}16.5 \pm 4.1 \\
8.8 \text { to } 24.2\end{array}$ & None above cut-off value \\
\hline 3 & Botsis 1999 [8] & $\begin{array}{l}\text { cross- } \\
\text { sectional }\end{array}$ & $\begin{array}{l}\text { EIA, Tumor markers CA } 153, \\
\text { Abbott AXSYM system, Abbott } \\
\text { Park, II, USA }\end{array}$ & $\begin{array}{l}\text { T1 } n=20 ; T 2 n=29 \\
\text { T3 } n=26\end{array}$ & $<33$ & $\begin{array}{l}18.0 \\
\text { (median) } \\
14 \text { to } 30 \\
\text { (range) }\end{array}$ & $\begin{array}{l}20 \\
1.0 \text { to } 34\end{array}$ & $\begin{array}{l}22 \\
12 \text { to } 41\end{array}$ & $\begin{array}{l}5 \%, 10 \% \text { and } 20 \% \text { above cut-off value, in } \\
\text { the } 3 \text { trimesters respectively }\end{array}$ \\
\hline 4 & Cheli 1999 [9] & $\begin{array}{l}\text { cross- } \\
\text { sectional }\end{array}$ & $\begin{array}{l}\text { Bayer Immuno } 1 \text { CA } 15-3 \text { assay, } \\
\text { Tarrytown, New York, USA) }\end{array}$ & $\begin{array}{l}\mathrm{T} 1 \mathrm{n}=32 ; \mathrm{T} 2 \mathrm{n}=5 \\
\mathrm{~T} 3 \mathrm{n}=53\end{array}$ & $<35$ & $\begin{array}{l}16.76 \\
\text { (mean) }\end{array}$ & - & 20.78 & $3.3 \%$ above cut-off value \\
\hline 5 & Bon 2001 [10] & $\begin{array}{l}\text { cross- } \\
\text { sectional }\end{array}$ & $\begin{array}{l}\text { Enzymun-Test CA 15-3 } \\
\text { (Boehringer, Mannheim, } \\
\text { Germany) }\end{array}$ & $\begin{array}{l}\text { T1 } n=127 ; T 2 n= \\
192 ; T 3 n=47\end{array}$ & $\begin{array}{l}\text { Not } \\
\text { stated }\end{array}$ & $\begin{array}{l}14.0 \\
\text { (median) } \\
5.0 \text { to } 32 \\
\text { (range) }\end{array}$ & $\begin{array}{l}15.0 \\
6.0 \text { to } 40\end{array}$ & $\begin{array}{l}26.0 \\
9 \text { to } 56\end{array}$ & $\begin{array}{l}\text { Raised above cut-off value, percentage not } \\
\text { stated }\end{array}$ \\
\hline 6 & Ercan 2011 [11] & longitudinal & $\begin{array}{l}\text { Modular Analytics E } 170 \text { Module } \\
\text { (Roche diagnostics), Basel, } \\
\text { Switserland. }\end{array}$ & $\mathrm{n}=30$ & $<25$ & $\begin{array}{l}17.5 \\
\text { (median) } \\
7.6 \text { to } 39.3 \\
\text { (range) }\end{array}$ & $\begin{array}{l}19.7 \\
10.4 \text { to } 39\end{array}$ & $\begin{array}{l}18.3 \\
7 \text { to } 38.6\end{array}$ & $16 \%$ above cut-off value \\
\hline
\end{tabular}

$\mathrm{SD}$, standard deviation; $\mathrm{T}$, trimester. 
Table 4 Overview of selected studies on carbohydrate antigen 125 levels during normal pregnancy.

\begin{tabular}{|c|c|c|c|c|c|c|c|c|c|}
\hline & $\begin{array}{l}\text { Author/year of } \\
\text { publication }\end{array}$ & Study design & Laboratory technique & $\begin{array}{l}\text { Number of } \\
\text { patients }\end{array}$ & $\begin{array}{l}\text { Cut-off } \\
\text { value } \\
(\mathrm{U} / \mathrm{mL})\end{array}$ & Trimester 1 & $\begin{array}{l}\text { Trimester } \\
2\end{array}$ & $\begin{array}{l}\text { Trimester } \\
3\end{array}$ & Conclusion \\
\hline 1 & Niloff 1984 [12] & cross-sectional & 125I-labeled OC125 & $N=101$ & $<65$ & $>65$ in $16 \%$ & $<65$ & $<65$ & T1: $16 \%$ above cut-off value \\
\hline 2 & Haga 1986 [13] & cross-sectional & Centocore Inc., Malvern, PA, USA & $\begin{array}{l}\mathrm{T} 1 \mathrm{n}=29 ; \mathrm{T} 2 \mathrm{n}= \\
21 ; \mathrm{T} 3 \mathrm{n}=21\end{array}$ & $<35$ & $\begin{array}{l}85 \pm 101 \\
\text { (mean } \pm \text { SD) } \\
18 \text { to } 550 \\
\text { (range) }\end{array}$ & $\begin{array}{l}20 \pm 10 \\
10 \text { to } 54\end{array}$ & $\begin{array}{l}25 \pm 27 \\
<8 \text { to } 140\end{array}$ & $\begin{array}{l}\text { Raised above cut-off value, } \\
\text { percentage not stated }\end{array}$ \\
\hline 3 & Jacobs 1988 [14] & cross-sectional & Abbott Laboratories, Chicago, IL, USA & $\begin{array}{l}\text { T1 } n=11 ; T 2 n=7 \\
\text { T3 } n=8\end{array}$ & $<35$ & $\begin{array}{l}53.6 \text { (median) } \\
15.6 \text { to } 268.3 \\
\text { (range) }\end{array}$ & $\begin{array}{l}18.5 \\
12.0 \text { to } \\
25.1\end{array}$ & $\begin{array}{l}19.2 \\
16.8 \text { to } \\
43.8\end{array}$ & $35 \%$ above cut-off value \\
\hline 4 & $\begin{array}{l}\text { Kobayashi } 1989 \\
\text { [15] }\end{array}$ & $\begin{array}{l}\text { both cross-sectional } \\
\text { and longitudinal }\end{array}$ & ORIS Industry, Censaclay, France & $\mathrm{n}=122$ & $<35$ & $\begin{array}{l}71.7 \pm 71.1 \\
(\text { mean } \pm \text { SD) }\end{array}$ & $19.1 \pm 7.0$ & $28.1 \pm 14.1$ & $\begin{array}{l}\text { Raised above cut-off value, } \\
\text { percentage not stated }\end{array}$ \\
\hline 5 & $\begin{array}{l}\text { Touitou } 1989 \\
\text { [16] }\end{array}$ & cross-sectional & $\begin{array}{l}\text { IRMA, CIS-Bio International, Gif-Sur-Yvette, } \\
\text { France }\end{array}$ & $\begin{array}{l}T 1 n=32 ; T 2 n= \\
32 ; T 3 n=36\end{array}$ & $<35$ & $\begin{array}{l}23.7 \pm 13.9 \\
(\text { mean } \pm \mathrm{SD})\end{array}$ & $14.8 \pm 8.0$ & $\begin{array}{l}22.1 \pm \\
17.1\end{array}$ & $8 \%$ above cut-off value \\
\hline 6 & $\begin{array}{l}\text { Kenemans } 1992 \\
{[17]}\end{array}$ & cross-sectional & $\begin{array}{l}\text { Enzymun CA } 125 \text { (Boehringer, Mannheim, } \\
\text { Germany) }\end{array}$ & $\begin{array}{l}T 1 n=26 ; T 2 n= \\
20 ; T 3 n=145\end{array}$ & $<35$ & $\begin{array}{l}24.4 \pm 13.3 \\
\text { (mean } \pm \text { SD) } \\
54.6 \\
\text { (maximum } \\
\text { range) }\end{array}$ & $\begin{array}{l}38.1 \pm \\
47.4 \\
166.6\end{array}$ & $\begin{array}{l}74.7 \pm \\
273.3 \\
2,419.7\end{array}$ & $\begin{array}{l}\text { T1: } 19 \% \text { above cut-off value } \\
\text { T2: } 15 \% \text { above cut-off value } \\
\text { T3: } 20 \% \text { above cut-off value }\end{array}$ \\
\hline 7 & $\begin{array}{l}\text { Schlageter } 1998 \\
\text { [7] }\end{array}$ & longitudinal & $\begin{array}{l}\text { ELSA-CA } 125 \text { (CIS Bio International-Bio } \\
\text { International, Gif-Sur-Yvette, France }\end{array}$ & $\mathrm{n}=12$ & $<40$ & $\begin{array}{l}18.7 \pm 14.0 \\
\text { (mean } \pm \text { SD) } \\
6.1 \text { to } 41.5 \\
\text { (range) }\end{array}$ & $\begin{array}{l}19.9 \pm \\
12.5 \\
6.5 \text { to } 54.3\end{array}$ & $\begin{array}{l}22.3 \pm \\
13.1 \\
6.1 \text { to } 51.3\end{array}$ & $\begin{array}{l}\text { Raised above cut-off value, } \\
\text { percentage not stated }\end{array}$ \\
\hline 8 & Spitzer 1998 [18] & longitudinal & $\begin{array}{l}\text { Centocore Inc., Diagnostic division, Malvern, } \\
\text { PA, USA }\end{array}$ & $n=20$ & $<35$ & $\begin{array}{l}33.1 \text { (median) } \\
3.7 \text { to } 251.2 \\
\text { (range) }\end{array}$ & $<35$ & $<35$ & $\begin{array}{l}\text { Raised above cut-off value, } \\
\text { percentage not stated }\end{array}$ \\
\hline 9 & Bon 2001 [10] & cross-sectional & $\begin{array}{l}\text { Enzymun-Test CA } 125 \text { (Boehringer, } \\
\text { Mannheim, Germany) }\end{array}$ & $\begin{array}{l}T 1 n=127 ; T 2 n= \\
192 ; T 3 n=47\end{array}$ & $\begin{array}{l}\text { Not } \\
\text { stated }\end{array}$ & $\begin{array}{l}23 \text { (median) } \\
4 \text { to } 108 \\
\text { (range) }\end{array}$ & $\begin{array}{l}14 \\
1 \text { to } 73\end{array}$ & $\begin{array}{l}21 \\
8 \text { to } 144\end{array}$ & $\begin{array}{l}\text { Raised above cut-off value, } \\
\text { percentage not stated }\end{array}$ \\
\hline 10 & Ercan 2012 [11] & longitudinal & $\begin{array}{l}\text { Modular Analytics E } 170 \text { Module (Roche } \\
\text { diagnostics, Basel, Switserland }\end{array}$ & $\mathrm{n}=30$ & $<35$ & $\begin{array}{l}19.0 \text { (median) } \\
4.9 \text { to } 61 \\
\text { (range) }\end{array}$ & $\begin{array}{l}15.6 \\
4.7 \text { to } 32.1\end{array}$ & $\begin{array}{l}19.6 \\
9.8 \text { to } 41.2\end{array}$ & 4.4\% above cut-off value \\
\hline
\end{tabular}

CA, carbohydrate antigen; ELISA, enzyme-linked immunosorbent assay; IRMA, immunoradiometric assay; SD: standard deviation; T, trimester; 


\section{Anti-Müllerian hormone}

AMH levels during the three trimesters of pregnancy were published in two articles. La Marca et al. [22] conducted a cross-sectional study in 27, 21 and 13 women in the three trimesters respectively, and found that serum AMH values were similar to those of non-pregnant women in the follicular phase, and tended to decrease with progression of the pregnancy. These findings were confirmed by Nelson et al. [23] in a prospective longitudinal cohort of 60 pregnant women, they also found normal levels during the first trimester, with a significant decline during the second and third trimester. Lutterodt et al. [24] compared first trimester AMH maternal serum levels in relation to the fetal sex (determined by $\mathrm{X}-\mathrm{Y}$ polymerase chain reaction of fetal tissue after elective termination of pregnancy), and no correlation was found.

\section{Germ cell tumor Lactate dehydrogenase}

During normal uncomplicated pregnancy, reported LDH values all remained below the normal cut-off values [25-28].

\section{Discussion}

Although tumor markers are very commonly used in clinical practice, their relevance and reliability is frequently debated. Tumor markers mainly have a supportive function, even for the routine care of non-pregnant patients. The role of tumor markers is limited in cases of cancer during pregnancy, or pregnancy after cancer, mainly due to their low specificity rate. Elevations are not always correlated with the presence of malignancy but are more often associated with normal physiologic changes of pregnancy. Moreover, obstetrical complications can induce even more variations. For example, elevated CA 125 has been associated with imminent miscarriage [29], and LDH is known to increase in cases of severe preeclampsia and HELLP (hemolysis, elevated liver function tests, low platelets) [26]. Physicians and midwives caring for pregnant women are well aware that the reference ranges of various laboratory values differ during pregnancy $[27,30]$, and this should also be the case with tumor markers in pregnancy (Table 1). Here, we summarize and explain the physiology of elevated levels during pregnancy for CA 15.3, SCC and CA 125. Inhibin- $\mathrm{B}, \mathrm{AMH}$ and $\mathrm{LDH}$ are not elevated during normal pregnancy.

CA $15-3$ is a well-characterized immunoassay that allows the detection of the mucin (MUC)-1 antigen. MUC-1 is part of the family of membrane-bound mucins, large glycoproteins, and their expression is frequently elevated in breast cancer cells. Elevated levels can be found in the serum of over $70 \%$ of patients with advanced breast cancer [31]. Conflicting data on the possible fetoplacental origin of CA 15-3 are reported. CA 15-3 concentrations in amniotic fluid and/or umbilical cord blood were analyzed and remained very low throughout pregnancy [32-34]; the authors concluded that the combination of an elevated maternal CA 15-3 and low levels in amniotic fluid and umbilical cord blood indicate that the antigen is not produced by the fetus, placenta or decidual tissue, and therefore, could not be considered as an oncofetal antigen [32-35]. However, MUC-1 has been detected in trophoblastic tissue even very early in pregnancy; placental expression increases as the pregnancy progresses and it is highly expressed throughout the third trimester $[36,37]$. Several authors have hypothesized that CA 15-3 elevations in maternal serum may result from the proliferation of maternal mammary gland epithelium late in pregnancy, with enhanced secretion of mucin, as opposed to placental transfer of the mucin $[9,10,35]$. Botsis et al. [8], and also Ercan et al. [11], asserted that CA 15-3 is independent of gestation and remains a reliable tumor marker for breast cancer during pregnancy. This statement is not in accordance with most other studies as found in this review. Although the reported values during pregnancy are only moderately elevated, we believe that caution is warranted, and a higher cut-off value would facilitate interpretation during pregnancy.

Elevated SCC serum levels are found in between 57\% and $70 \%$ of women with a primary squamous cell carcinoma of the cervix. Elevated levels are also found in between $24 \%$ and $53 \%$ of patients with squamous cell carcinomas of the head and neck, esophagus, and lung, and also in between $8 \%$ and $42 \%$ of patients with adenocarcinomas of the ovary and uterus [38]. SCC is probably a marker of cellular differentiation for squamous cells, as the incidence of elevated serum levels is higher in women with grade $1(78 \%)$ and grade $2(67 \%)$ carcinomas than in those with grade 3 tumors (38\% )[38]. Sarandakou et al. sampled maternal serum, umbilical cord blood and amniotic fluid during delivery of 56 full-termed pregnancies [39]; they found a high incidence of SCC levels above the cutoff value of $\leq 2.5 \mu \mathrm{g} / \mathrm{L}$ (30\% in maternal serum and $75 \%$ in umbilical cord blood). The levels found in amniotic fluid were extremely high (median $710 \mu \mathrm{g} / \mathrm{L}$; range 30 to 7,692 $\mu \mathrm{g} / \mathrm{L}$ ), which led the authors to conclude that SCC is an oncofetal antigen [39]. The analysis of in vitro culture of amnion cells and amniotic membranes revealed no accumulation of SCC in the supernatant, and no mRNA expression of SCC was found in the amnion, the cord or the placenta using a northern blot with a cDNA probe of SCC [40]. Therefore, it is more likely that the fetus, and not the placenta, is the origin of SCC found in amniotic fluid, but this remains to be confirmed.

CA 125 is used for monitoring non-mucinous epithelial ovarian cancer $[7,41]$. Of patients with ovarian 
carcinoma, 82\% have CA 125 levels $>35 \mathrm{U} / \mathrm{mL}$, compared with $1 \%$ of apparently healthy non-pregnant individuals. During pregnancy, CA 125 is present in relatively high concentrations in decidual cells, amniotic fluid and amnion cells, and significantly lower levels are found in umbilical cord blood, suggesting that decidua and amnion cells (and not the fetus) produce and secrete CA 125 into the amniotic fluid $[39,41,42]$. Interestingly, the molecular weight of CA 125 identified in pregnancy was significantly higher than that observed in ovarian cancer, suggesting a different production and/or metabolism of CA 125 glycoprotein for different tissues [35]. The large molecular weight of CA 125 in the fetoplacental unit prevents the passage of the antigen through the basal membranes. Therefore, a large difference exists between amniotic fluid and maternal serum concentrations of CA 125; disruption of the basal membranes can cause a higher permeability from the fetoplacental unit into the maternal circulation [39]. Higher maternal serum CA 125 levels in the first trimester can be explained by the process of trophoblast invasion in the decidua during placentation. Higher levels in the third trimester, and more particularly in the puerperium, can be caused by detachment of the placenta from the uterus, during which time decidual CA 125 might reach the maternal circulation [10].

In persisting adnexal masses during pregnancy, expert ultrasonographic assessment plays a pivotal role in estimating the risk of malignancy, and planning conservative management for an adnexal mass that is probably benign versus surgical treatment during pregnancy for an adnexal mass that has malignant characteristics [43,44]. Ovarian cancer during pregnancy is very rare and has an estimated incidence of 1 in 12,000 to 47,000 pregnancies [43]. When uncertainty remains towards the type of adnexal mass, despite expert evaluation, tumor markers might be important to help formulate the differential diagnosis. From the data presented, it is clear that the usefulness of CA 125 in pregnant women must be carefully considered, as it is evident that maternal serum CA 125 concentrations are influenced by pregnancy, especially during the first trimester. Thus, an adjusted cut-off level should be established in order to interpret CA 125 levels in pregnant patients [35]. Inhibin B and $\mathrm{AMH}$ are both serum markers for granulosa cell tumors. Granulosa cell tumors represent about $5 \%$ of all primary ovarian neoplasms, and the juvenile type has a higher incidence in children and young women. Currently, there is no evidence-based preference to use inhibin B or AMH as tumor marker in the non-pregnant patient [45]. During pregnancy, an apparent increase in inhibin B immunoreactivity may reflect some cross-reaction with inhibin A. Consequently, it is to be expected that AMH measurements are more reliable during pregnancy than inhibin $\mathrm{B}$.

\section{Risk of bias}

We aimed to minimize risk of bias of individual studies by excluding all studies reporting tumor markers measured in pregnancies with pathology (for example, miscarriage, intrauterine growth restriction, preeclampsia, aneuploidy) and/or without specification of gestational age. Publication bias and selective reporting within studies is not expected for this research area.

\section{Limitations of the present review and aims for future research}

There is no consensus on the clinical benefit of tumor markers and staging procedures. As a result, their practical use differs significantly among centers. Despite this, tumor markers are frequently used in clinical practice. When measured in the pregnant patient, the pregnancyrelated physiologic alterations render the interpretation of tumor marker values more difficult. Therefore, we aimed to provide a better knowledge of tumor marker values during pregnancy. The available literature remains inconclusive for several reasons. The majority of studies were cross-sectional and used small cohorts, which may have led to underpowered conclusions. Comparability of study results is further complicated by the different definitions used for the three trimesters of pregnancy and, even more important, by the various types of assays with different intra-and inter-assay coefficients of variation and corresponding different degrees of precision, which were not always mentioned. Confidence intervals and standard deviations were not systematically stated, hence, outliers could not always be excluded. Normal values for pregnant women are still not well established. A longitudinal prospective study with sufficient participants to correct for interpatient heterogeneity would be more suitable to define the $2.5^{\text {th }}$ and $97.5^{\text {th }}$ percentiles for the different tumor markers during pregnancy [1].

Human epididymis secretory protein 4 (HE4, also known as WFDC2) is a new marker for epithelial ovarian carcinoma [46]. HE4 was first proposed as a serum tumor marker for ovarian cancer in 2003 [47]. So far, its value as an additional marker alongside CA 125 is still under debate $[48,49]$. Interestingly, HE4 has an increased performance in the premenopausal group, mainly because, unlike CA 125, it is not overexpressed in cases of endometriosis [50]. The expression of HE4 during normal pregnancy deserves further investigation.

\section{Conclusion}

Based on this review, we can conclude that CA 125 values can be raised during pregnancy and both CA 15.3 and SCC levels generally remain below the cut-off values, although higher levels are not uncommon. Inhibin B, $\mathrm{AMH}$ and LDH levels are not elevated in maternal serum during normal pregnancy. Despite its aforementioned 
limitations, the reference table we have assembled provides a quick reference for gynecological tumor markers during pregnancy.

\section{Abbreviations}

AFP: a-fetoprotein; AMH: anti-Müllerian hormone; CA: cancer antigen; HE4: human epididymis secretory protein 4; LDH: lactate dehydrogenase; MUC-1: mucin-1; SCC: squamous-cell carcinoma antigen; SD: standard deviation.

\section{Acknowledgements}

This research was funded by the Research Foundation-Flanders and Belgian Cancer Plan, Ministry of Health.

\section{Author details}

'Leuven Cancer Institute, Gynecologic Oncology, University Hospitals Leuven, KU Leuven, Belgium. ${ }^{2}$ Department of Obstetrics and Gynecology, Jessa Hospital, Hasselt, Belgium. ${ }^{3}$ Foeto-Maternal Unit, University Hospitals Leuven, KU Leuven, Belgium.

\section{Authors' contributions}

$\mathrm{SH}$ developed the concept for the review with $\mathrm{MH}$ and FA. Literature research, data interpretation and first manuscript draft were done by $\mathrm{SH}$ and AL. SH, AL, MMG, KVC, MH and FA critically revised the content. All authors read and approved the final version.

\section{Competing interests}

The authors declare that they have no competing interests.

Received: 7 February 2012 Accepted: 8 August 2012

Published: 8 August 2012

\section{References}

1. Kulasingam V, Diamandis EP: Strategies for discovering novel cancer biomarkers through utilization of emerging technologies. Nat Clin Pract Oncol 2008, 5:588-599.

2. Rustin GJ, van der Burg ME, Griffin CL, Guthrie D, Lamont A, Jayson GC, Kristensen G, Mediola C, Coens C, Qian W, Parmar MK, Swart AM, MRC OV05; EORTC 55955 investigators: Early versus delayed treatment of relapsed ovarian cancer (MRC OV05/EORTC 55955): a randomised trial. Lancet 2010, 376:1155-1163.

3. Van Calsteren K, Heyns L, De Smet F, Van Eycken L, Gziri MM, Van Gemert W, Halaska M, Vergote I, Ottevanger N, Amant F: Cancer during pregnancy: an analysis of 215 patients emphasizing the obstetrical and the neonatal outcomes. J Clin Oncol 2010, 28:683-689.

4. Stensheim H, Moller B, van DT, Fossa SD: Cause-specific survival for women diagnosed with cancer during pregnancy or lactation: a registrybased cohort study. J Clin Oncol 2009, 27:45-51.

5. Stensheim H, Cvancarova M, Moller B, Fossa SD: Pregnancy after adolescent and adult cancer: a population-based matched cohort study. Int J Cancer 2011, 129:1225-1236.

6. Touitou Y, Darbois Y, Bogdan A, Auzeby A, Keusseoglou S: Tumour marker antigens during menses and pregnancy. Br J Cancer 1989, 60:419-420.

7. Schlageter MH, Larghero J, Cassinat B, Toubert ME, Borschneck C, Rain JD: Serum carcinoembryonic antigen, cancer antigen 125 , cancer antigen 15-3, squamous cell carcinoma, and tumor-associated trypsin inhibitor concentrations during healthy pregnancy. Clin Chem 1998, 44:1995-1998.

8. Botsis D, Sarandakou A, Kassanos D, Kontoravdis A, Rizos D, Protonotariou E, Phocas I, Creatsas G: Breast cancer markers during normal pregnancy. Anticancer Res 1999, 19:3539-3541.

9. Cheli CD, Morris DL, Neaman IE, Dai J, Allard WJ, Yeung KK: Measurement of four tumor marker antigens in the sera of pregnant women. J Clin Lab Anal 1999, 13:35-39.

10. Bon GG, Kenemans P, Verstraeten AA, Go S, Philipi PA, van Kamp GJ, van Geijn HP, van Vugt JM: Maternal serum Ca125 and Ca15-3 antigen levels in normal and pathological pregnancy. Fetal Diagn Ther 2001, 16:166-172.

11. Ercan S, Kaymaz O, Yucel N, Orcun A: Serum concentrations of CA 125, CA 15-3, CA 19-9 and CEA in normal pregnancy: a longitudinal study. Arch Gynecol Obstet 2012, 285:579-584.
12. Niloff JM, Knapp RC, Schaetzl E, Reynolds C, Bast RC Jr: CA125 antigen levels in obstetric and gynecologic patients. Obstet Gynecol 1984, 64:703-707.

13. Haga Y, Sakamoto K, Egami H, Yoshimura R, Akagi M: Evaluation of serum CA125 values in healthy individuals and pregnant women. Am J Med Sci 1986, 292:25-29.

14. Jacobs IJ, Fay TN, Stabile I, Bridges JE, Oram DH, Grudzinskas JG: The distribution of CA 125 in the reproductive tract of pregnant and nonpregnant women. Br J Obstet Gynaecol 1988, 95:1190-1194.

15. Kobayashi F, Sagawa N, Nakamura K, Nonogaki M, Ban C, Fujii S, Mori T: Mechanism and clinical significance of elevated CA 125 levels in the sera of pregnant women. Am J Obstet Gynecol 1989, 160:563-566.

16. Touitou Y, Bogdan A, Darbois Y: CA-125 ovarian cancer associated antigen in cancer and pregnancy: interpretation of enzyme immunoassay and immunoradiometric assay. Anticancer Res 1989, 9:1805-1807

17. Kenemans P, Bon GG, Kessler AC, Verstraeten AA, van Kamp GJ: Multicenter technical and clinical evaluation of a fully automated enzyme immunoassay for CA 125. Clin Chem 1992, 38:1466-1471.

18. Spitzer M, Kaushal N, Benjamin F: Maternal CA-125 levels in pregnancy and the puerperium. J Reprod Med 1998, 43:387-392.

19. Petraglia F, Luisi S, Benedetto C, Zonca M, Florio P, Casarosa E, Volpe A, Bernasconi S, Genazzani AR: Changes of dimeric inhibin B levels in maternal serum throughout healthy gestation and in women with gestational diseases. J Clin Endocrinol Metab 1997, 82:2991-2995.

20. Fowler PA, Evans LW, Groome NP, Templeton A, Knight PG: A longitudinal study of maternal serum inhibin-A, inhibin- $B$, activin- $A$, activin- $A B$, proalphaC and follistatin during pregnancy. Hum Reprod 1998, 13:3530-3536.

21. Wallace EM, Riley SC, Crossley JA, Ritoe SC, Horne A, Shade M, Groome NP: Dimeric inhibins in amniotic fluid, maternal serum, and fetal serum in human pregnancy. J Clin Endocrinol Metab 1997, 82:218-222.

22. La Marca A, Giulini S, Orvieto R, De L, Volpe A: Anti-Mullerian hormone concentrations in maternal serum during pregnancy. Hum Reprod 2005, 20:1569-1572.

23. Nelson SM, Stewart F, Fleming R, Freeman DJ: Longitudinal assessment of antimullerian hormone during pregnancy-relationship with maternal adiposity, insulin, and adiponectin. Fertil Steril 2010, 93:1356-1358.

24. Lutterodt M, Byskov AG, Skouby SO, Tabor A, Yding AC: Anti-Mullerian hormone in pregnant women in relation to other hormones, fetal sex and in circulation of second trimester fetuses. Reprod Biomed Online 2009, 18:694-699.

25. van Buul EJ, Steegers EA, Jongsma HW, Eskes TK, Thomas CM, Hein PR: Haematological and biochemical profile of uncomplicated pregnancy in nulliparous women; a longitudinal study. Neth J Med 1995, 46:73-85.

26. He S, Bremme K, Kallner A, Blomback M: Increased concentrations of lactate dehydrogenase in pregnancy with preeclampsia: a predictor for the birth of small-for-gestational-age infants. Gynecol Obstet Invest 1995, 39:234-238.

27. Larsson A, Palm M, Hansson LO, Axelsson O: Reference values for clinical chemistry tests during normal pregnancy. BJOG 2008, 115:874-881.

28. Makkonen M, Penttila IM, Castren O: Serum lactic acid dehydrogenase and isoenzymes during pregnancy and labor. Acta Obstet Gynecol Scand 1980, 59:97-102

29. Fiegler P, Katz M, Kaminski K, Rudol G: Clinical value of a single serum CA125 level in women with symptoms of imminent abortion during the first trimester of pregnancy. J Reprod Med 2003, 48:982-988.

30. Abbassi-Ghanavati $M$, Greer LG, Cunningham FG: Pregnancy and laboratory studies: a reference table for clinicians. Obstet Gynecol 2009, 114:1326-1331.

31. Hayes DF, Zurawski VR Jr, Kufe DW: Comparison of circulating CA15-3 and carcinoembryonic antigen levels in patients with breast cancer. J Clin Oncol 1986, 4:1542-1550.

32. Lelle RJ, Henkel E, Leinemann D, Goeschen K: Measurement of CEA, TPA, neopterin, CA125, CA153 and CA199 in sera of pregnant women, umbilical cord blood and amniotic fluid. Gynecol Obstet Invest 1989, 27:137-142.

33. Tayyar M, Tutus A: The effect of maternal age, parity, and fetal sex on the amniotic fluid and maternal serum levels of CA 125, CA 19.9, CA 15.3, and CEA. Int J Fertil Womens Med 1999, 44:256-259.

34. Kiran G, Kiran H, Guler FI, Ekerbicer HC, Kilinc M: Maternal serum and umbilical cord tumor marker levels at term pregnancy. Acta Obstet Gynecol Scand 2005, 84:85-89. 
35. Sarandakou A, Protonotariou E, Rizos D: Tumor markers in biological fluids associated with pregnancy. Crit Rev Clin Lab Sci 2007, 44:151-178.

36. Shyu MK, Lin MC, Liu CH, Fu YR, Shih JC, Lee CN, Chen HY, Huang J, Huang MC, Hsieh FJ: MUC1 expression is increased during human placental development and suppresses trophoblast-like cell invasion in vitro. Biol Reprod 2008, 79:233-239.

37. Scholz C, Hermann C, Kachler A, Kainer F, Friese K, Makrigiannakis A, et al: Association of placental inflammation with fetomaternal hemorrhage and loss of placental mucin-1. Arch Gynecol Obstet 2012, 285:605-612.

38. Crombach G, Scharl A, Vierbuchen M, Wurz H, Bolte A: Detection of squamous cell carcinoma antigen in normal squamous epithelia and in squamous cell carcinomas of the uterine cervix. Cancer 1989, 63:1337-1342.

39. Sarandakou A, Kontoravdis A, Kontogeorgi Z, Rizos D, Phocas I: Expression of CEA, CA-125 and SCC antigen by biological fluids associated with pregnancy. Eur J Obstet Gynecol Reprod Biol 1992, 44:215-220.

40. Takeshima N, Suminami Y, Takeda O, Abe H, Kato H: Origin of CA125 and SCC antigen in human amniotic fluid. Asia Oceania J Obstet Gynaecol 1993, 19:199-204.

41. Bast RC Jr, XU FJ, Yu YH, Barnhill S, Zhang Z, Mills GB: CA 125: the past and the future. Int J Biol Markers 1998, 13:179-187.

42. Kobayashi F, Sagawa N, Nanbu Y, Nakamura K, Nonogaki M, Ban C, Fujii S, Mori T: Immunohistochemical localization and tissue levels of tumorassociated glycoproteins CA 125 and CA 19-9 in the decidua and fetal membranes at various gestational ages. Am J Obstet Gynecol 1989, 160:1232-1238.

43. Aggarwal P, Kehoe S: Ovarian tumours in pregnancy: a literature review. Eur J Obstet Gynecol Reprod Biol 2011, 155:119-124.

44. Timmerman D, Ameye L, Fischerova D, Epstein E, Melis GB, Guerriero S, van Holsbeke C, Savelli L, Fruscio R, Lissoni AA, Testa AC, Veldman J, Vergote I, Van Huffel S, Bourne T, Valentin L: Simple ultrasound rules to distinguish between benign and malignant adnexal masses before surgery: prospective validation by IOTA group. BMJ 2010, 341:C6839.

45. Geerts I, Vergote I, Neven P, Billen J: The role of inhibins B and antimullerian hormone for diagnosis and follow-up of granulosa cell tumors. Int J Gynecol Cancer 2009, 19:847-855.

46. Bingle $L$, Singleton $V$, Bingle CD: The putative ovarian tumour marker gene HE4 (WFDC2), is expressed in normal tissues and undergoes complex alternative splicing to yield multiple protein isoforms. Oncogene 2002, 21:2768-2773.

47. Hellstrom I, Raycraft J, Hayden-Ledbetter M, Ledbetter JA, Schummer M, Mclntosh M, Drescher C, Urban N, Hellström KE: The HE4 (WFDC2) protein is a biomarker for ovarian carcinoma. Cancer Res 2003, 63:3695-3700.

48. Moore RG, Brown AK, Miller MC, Skates S, Allard WJ, Verch T, Steinhoff M, Messerlian G, DiSilvestro P, Granai CO, Bast RC Jr: The use of multiple novel tumor biomarkers for the detection of ovarian carcinoma in patients with a pelvic mass. Gynecol Oncol 2008, 108:402-408.

49. Van Gorp T, Cadron I, Despierre E, Daemen A, Leunen K, Amant F, Timmerman D, De Moor B, Vergote I: HE4 and CA125 as a diagnostic test in ovarian cancer: prospective validation of the Risk of Ovarian Malignancy Algorithm. Br J Cancer 2011, 104:863-870.

50. Huhtinen K, Suvitie P, Hiissa J, Junnila J, Huvila J, Kujari H, Setälä M, Härkki P, Jalkanen J, Fraser J, Mäkinen J, Auranen A, Poutanen M, Perheentupa A: Serum HE4 concentration differentiates malignant ovarian tumours from ovarian endometriotic cysts. Br J Cancer 2009, 100:1315-1319.

51. Montz FJ, Horenstein J, Platt LD, d'Ablaing G, Schlaerth JB, Cunningham G The diagnosis of immature teratoma by maternal serum alphafetoprotein screening. Obstet Gynecol 1989, 73:522-525.

52. Wisser J, Florio I, Neff M, Konig V, Huch R, Huch A, von Mandach U: Changes in bone density and metabolism in pregnancy. Acta Obstet Gynecol Scand 2005, 84:349-354.

Pre-publication history

The pre-publication history for this paper can be accessed here: http://www.biomedcentral.com/1741-7015/10/86/prepub

doi:10.1186/1741-7015-10-86

Cite this article as: Han et al: Physiologic variations of serum tumor markers in gynecological malignancies during pregnancy: a systematic review. BMC Medicine 2012 10:86.

\section{Submit your next manuscript to BioMed Central and take full advantage of:}

- Convenient online submission

- Thorough peer review

- No space constraints or color figure charges

- Immediate publication on acceptance

- Inclusion in PubMed, CAS, Scopus and Google Scholar

- Research which is freely available for redistribution

Submit your manuscript at www.biomedcentral.com/submit
Ciomed Central 